\title{
Pemasangan Lampu Jalan dan Pembangunan Pembangkit Listrik Berbasis Solar Cell Sebagai Prototype Pembelajaran Energi Terbarukan Di MA Al-Khairiyah Rancaranji
}

\author{
Septianissa Azzahra ${ }^{1}$; Samsurizal ${ }^{2}$; Christiono ${ }^{3}$; Miftahul Fikri ${ }^{4}$; \\ Muhammad Luthfiansyah ${ }^{5}$; Abdul malik ${ }^{6}$ \\ 1, 2, 3, 4, 5, 6 Institut Teknologi PLN \\ ${ }^{1}$ septianissa@itpln.ac.id
}

\begin{abstract}
Renewable energy, especially solar power plants (PLTS), is now begin to develop their applications to many forms, such as: installed as a home power supply, power supply for buildings, and also as power supply for street lighting (solar street light). Madrasah Aliyah Al-Khairiyah Rancranji In this regard, as a partner, demand a socialization and a study for their students to understand more about renewable energy topics especially about solar energy. And the limited electric power is also one of the problems for this school. Therefore, PKM activity in Madrasah Aliyah Al-Khairiyah Rancaranji is a solution given by the PKM team by providing learning and an introduction of renewable energy as well as workshop and installation of PLTS and road lamps based on solar cell. Results gained after the implementation of this activity are students understand and knows about the renewable energy, its application and its benefits in daily life.
\end{abstract}

Keyword: Renewable Energy, PLTS, Solar Cell

\begin{abstract}
ABSTRAK
Energi terbarukan khususnya Pembangkit listrik tenaga surya (PLTS) saat ini sudah mulai banyak dikembangkan penerapannya, antara lain dalam bentuk yang dipasang sebagai penyuplai daya rumah, penyuplai daya untuk gedung, dan juga penyuplai daya untuk lampu penerangan jalan. Madrasah Aliyah Al-Khairiyah Rancranji dalam hal ini sebagai mitra, sangat memerlukan adanya sosialisasi atau pembelajaran bagi siswa/i nya untuk lebih memahami tentang energi baru dan terbarukan khususnya energi surya. Serta terbatasnya penerangan pada sekolah ini juga menjadi salah satu permasalahan bagi mitra. Oleh karena itu, kegiatan PKM pada MA Al-Khairiyah Rancaranji ini merupakan solusi yang diberikan oleh Tim PKM dengan memberikan pembelajaran dan pengenalan mengenai energi terbarukan serta workshop dan pemasangan PLTS dan lampu jalan yang berbasis solar cell. Hasil yang didapat setelah dilaksanakannya kegiatan ini adalah siswa/i memahami dan mengenal energi terbarukan serta penerapan dan manfaatnya dalam kehidupan sehari-hari.
\end{abstract}

Kata Kunci: Energi Terbarukan, PLTS, Solar Cell 


\section{PENDAHULUAN}

Indonesia memiliki banyak potensi energi terbarukan, seperti tenaga air (termasuk minihidro), panas bumi, biomasa, angin dan surya (matahari) yang bersih dan ramah lingkungan, tetapi pemanfaatannya belum optimal ${ }^{[5]}$. Karena letaknya yang berada di garis khatulistiwa, sehingga Indonesia mempunyai sumber energi surya yang berlimpah dengan intensitas radiasi matahari rata-rata sekitar $4,8 \mathrm{KWh} / \mathrm{m}^{2}$ per hari di seluruh wilayah Indonesia. Dengan berlimpahnya sumber energi surya yang belum dimanfaatkan secara optimal, sedangkan di sisi lain ada sebagian wilayah Indonesia yang belum terlistriki karena tidak terjangkau oleh jaringan listrik PLN, sehingga Pembangkit Listrik Tenaga Surya (PLTS) dengan sistemnya yang modular dan mudah dipindahkan merupakan salah satu solusi yang dapat dipertimbangkan sebagai salah satu pembangkit listrik alternatif ${ }^{[2]}$.

Salah satu lokasi yang terkendala dalam hal penerangan ketika kegiatan mencapai malam hari serta beberapa kali terjadi pemadaman listrik yaitu di MA Al- Khairiyah Rancaranji. Oleh karena itu kami dari dosen dan mahasiswa IT-PLN menjadikan MA Al- Khairiyah Rancaranji sebagai mitra kami dalam kegiatan Pengabdian Kepada Masyarakat. Kegiatan ini merupakan bagian dari tridarma perguruan tinggi. Judul dari kegiatan tersebut yaitu "Pemasangan Lampu Jalan Dan Pembangunan Pembangkit Listrik Berbasis Solar Cell Sebagai Prototype Pembelajaran Energi Terbarukan Di Ma Al-Khairiyah Rancaranji”.

\section{METODE PELAKSANAAN KEGIATAN}

Penerima manfaat dari Pemasangan Lampu Jalan dan pembangunan Pembangkit Listrik Berbasis Solar Cell ini adalah civitas MA Al-Khairiyah Rancaranji. Sehingga diharapkan dapat menunjang kegiatan di sekitar lokasi tersebut. Kemudian dengan pemasangan Pembangkit Listrik Berbasis Solar Cell ini dapat memperkenalkan bentuk penerapan energi baru terbarukan dalam teknologi kelistrikan.

Bentuk kegiatan yang akan dilakukan adalah pemaparan mengenai pemanfaatan Solar Cell sebagai salah satu teknologi yang dapat digunakan sebagai sumber energi untuk membangkitkan energi listrik yang kemudian dapat digunakan sebagai pembangkit listrik mandiri serta sebagai sarana pembelajaran bagi civitas sekolah tersebut. Bersama dengan kepala sekolah dan guru-guru melakukan pengecekan dan pengujian peralatan yang akan digunakan. Setelah melakukan pengecekan dan pengujian alat dilakukan pemasangan lampu jalan dan pembangunan pembangkit listrik berbasis Solar Cell.

Berikut adalah metode yang dilakukan pada kegiatan pengabdian kepada masyarakat di MA Al-Khairiyah Rancaranji:

1. Kunjungan tim ke MA Al-Khairiyah Rancaranji

2. Pembelajaran dan Pengenalan kepada Siswa/I mengenai Energi Baru dan Terbarukan

3. Workshop pengenalan dan pemasangan pembangkit tenaga listrik surya (PLTS)

4. Pemasangan lampu jalan berbasis solar cell

\section{HASIL DAN LUARAN YANG DICAPAI}

\subsection{Kunjungan Tim PKM}

Tim PKM Teknik Elektro Institut Teknologi PLN telah melakukan kunjungan ke MA AlKhairiyah Rancaranji, Kecamatan Padarincang, Kabupaten Serang, Banten. Pada tanggal 20 September 2019. Kunjuangan yang dilakukan adalah kunjungan pendahuluan yang bertujuan untuk menyurvei lokasi mitra. Kemudian membahas langkah selanjutnya 
dalam pelaksanaan program pengabdian pada masyarakat (PKM) di MA Al-Khairiyah Rancaranji.

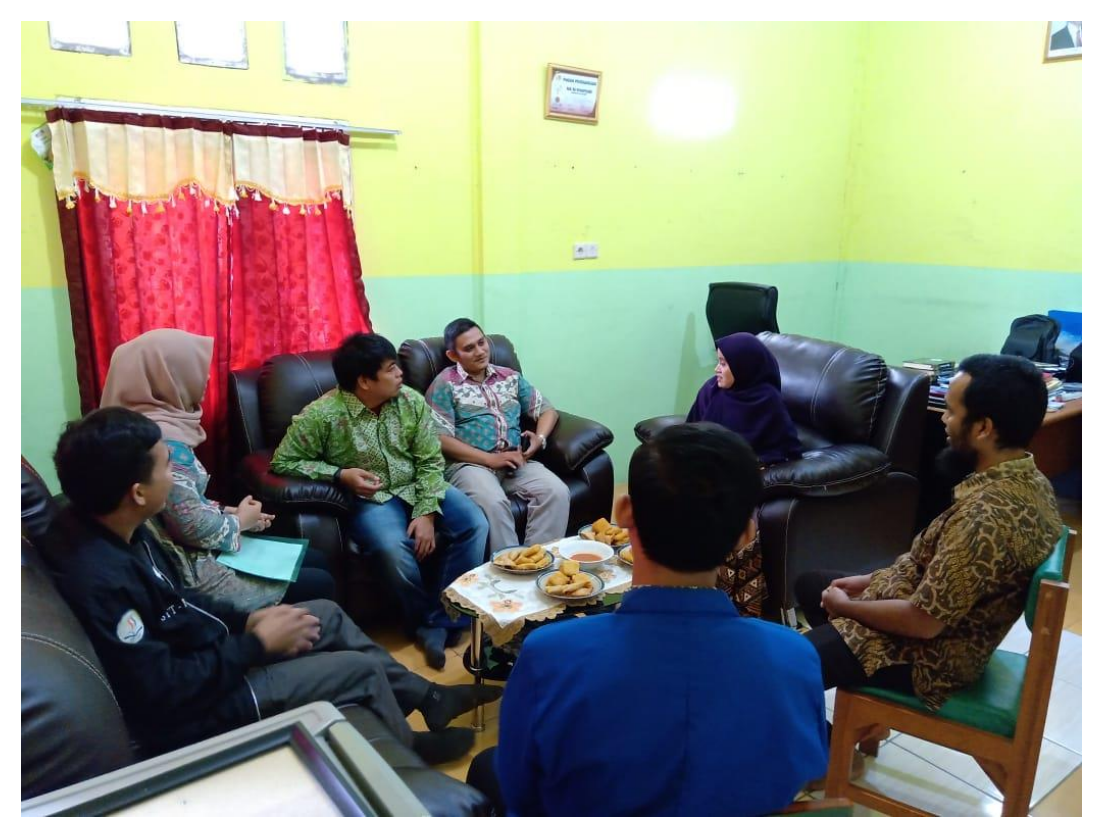

Gambar 1. Kunjungan Tim PKM Ke MA Al-Khairiyah Rancaranji

\subsection{Pembelajaran mengenai Energi Terbarukan}

Dalam memperkenalkan energi baru terbarukan, tim PKM Institut Teknologi PLN melakukan kegiatan penyuluhan tentang energi baru terbarukan kepada siswa siswi MA AlKhairiyah Rancaranji.
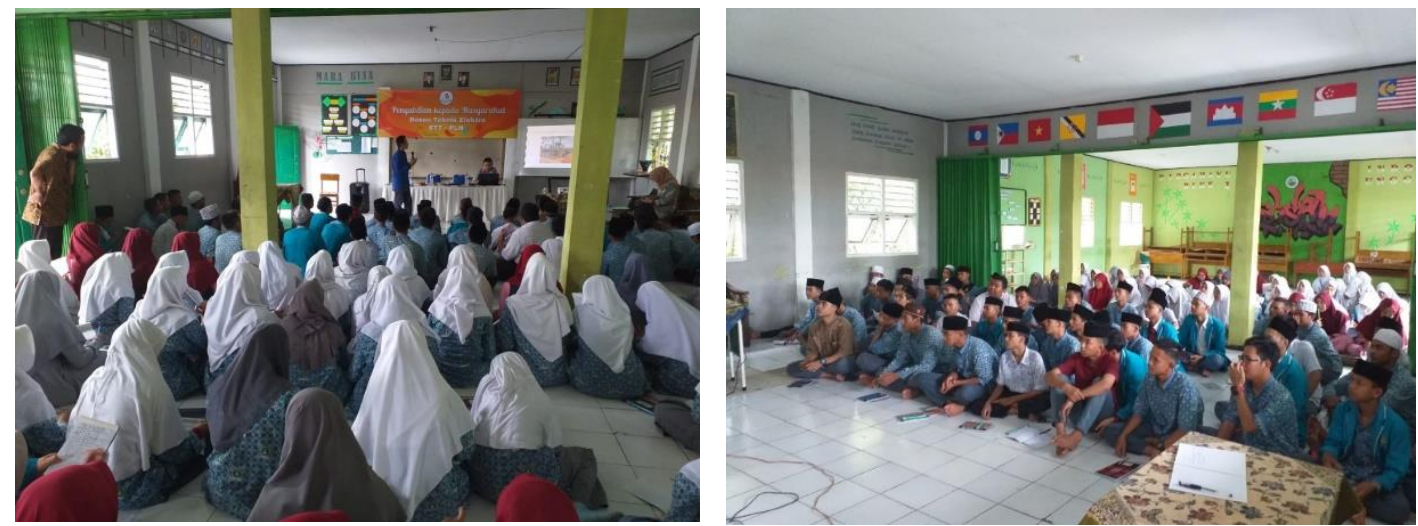

Gambar 2. Kegiatan Pembelajaran Energi Baru Terbarukan

Setelah diadakannya kegiatan pengenalan energi terbarukan kepada siswa siswi maupun civitas MA Al-Khairiyah Rancaranji. Dapat diketahui bahwa sebagian besar sudah memahami dengan baik tentang energi baru terbarukan yang dapat dilihat dari antusias saat menerima materi presentasi dan aktif dalam bertanya maupun menjawab pertanyaan yang diberikan oleh tim PKM. 


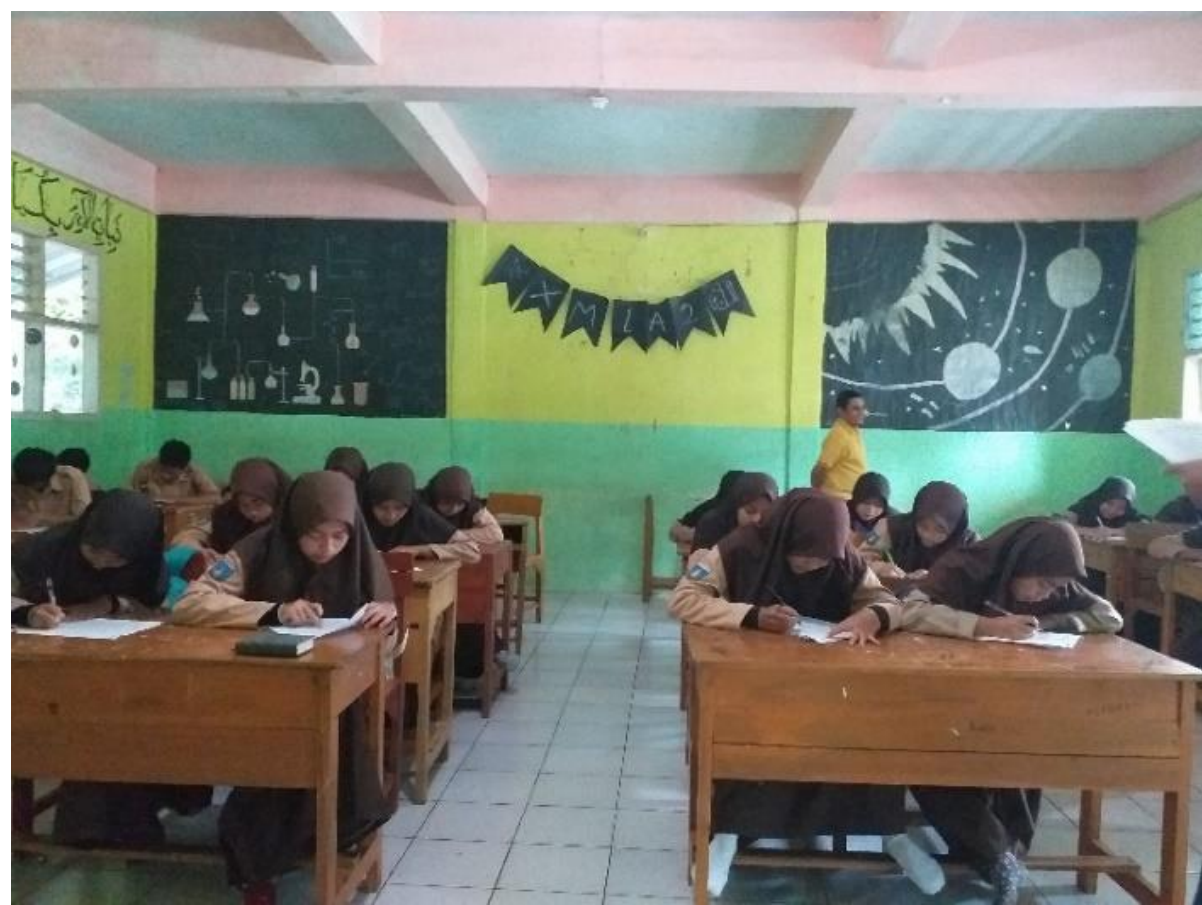

Gambar 3. Tes Pemahaman mengenai Energi Baru Terbarukan

Siswa-siswi diberikan soal pemahaman mengenai energi baru terbarukan (EBT) setelah diterangkan mengenai energi baru terbarukan oleh mahasiswa IT-PLN. Soal pemahaman berisikan materi yang telah dijelaskan saat presentasi seperti pengertian tentang EBT, potensi EBT di Indonesia, penjelasan tentang solar cell, dan pemanfaatan solar cell dalam menunjang kehidupan di masyarakat. Sehingga dengan ini siswa-siswi dapat lebih memahami tentang energi baru terbarukan yang ada di indonesia dan dapat menerapkannya.

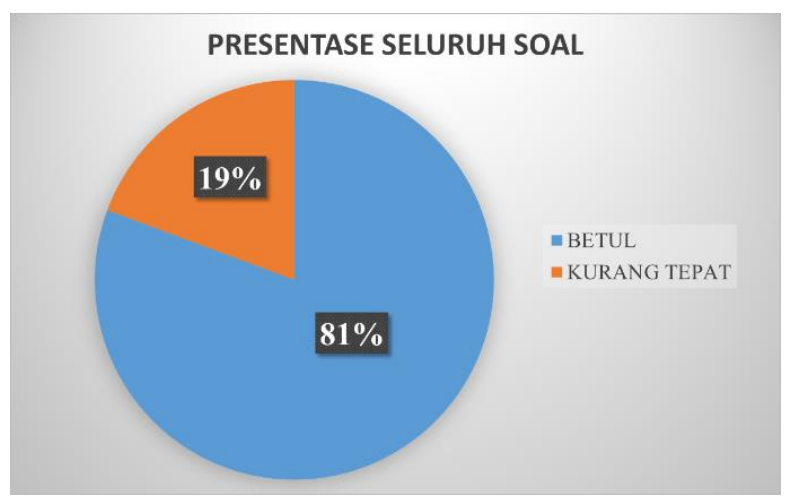

Gambar 4. Hasil Tes Pemahaman Siswa-Siswi

\subsection{Workshop Pembangkit Tenaga Surya}

Kegiatan ini diawali dengan penjelasan tentang pembangkit listrik tenaga surya. Kemudian jenis-jenis solar panel yang dapat digunakan seperti monocrystaline, polycrystaline, dan panel thin film. Selanjutnya dijelaskan tentang komponen-komponen PLTS yang perlu digunakan sehingga dapat bekerja sesuai dengan fungsinya. Lalu komponen-komponen tersebut dirakit dengan komponen-komponen lainnya dibantu oleh siswa-siswi MA Al-Khairiyah Rancaranji. Setelah semua terpasang, selanjutnya dicoba untuk mengisi daya ponsel untuk melihat perubahan energi sinar matahari menjadi energi listrik. 
Kegiatan workshop dilakukan di halaman sekolah setelah kegiatan pembelajaran tentang energi baru terbarukan dan PLTS dilaksanakan di dalam kelas. Sehingga setelah siswa-siswi menerima materi secara teori-teori yang telah di jelaskan, selanjutnya dapat di praktekan dengan melihat alatnya secara langsung.
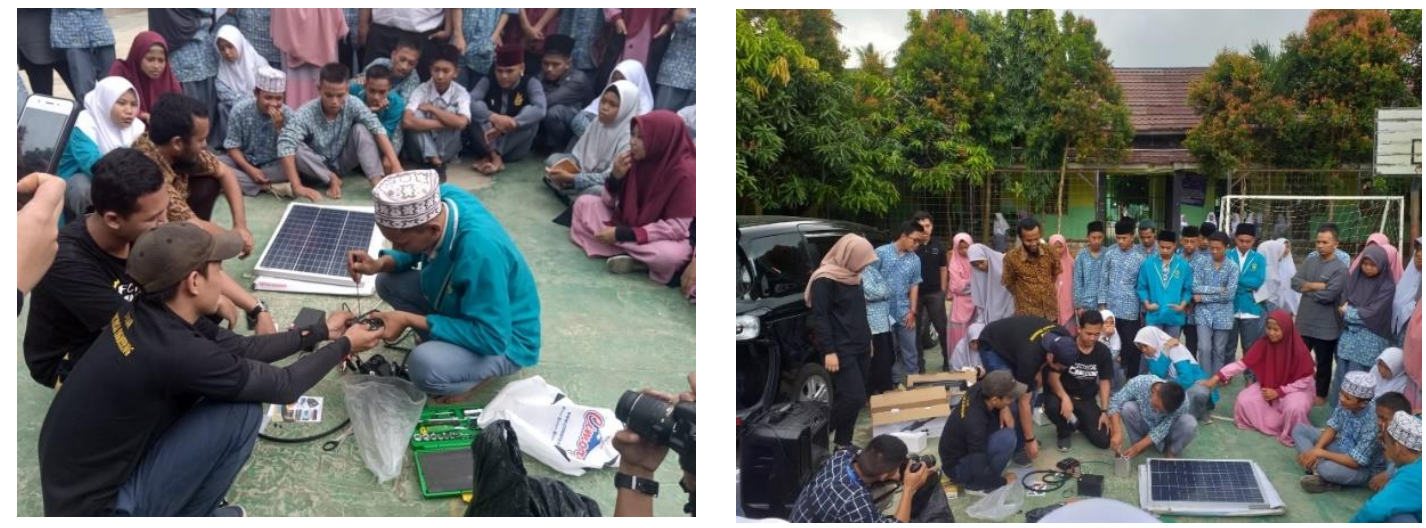

Gambar 5. Workshop pengenalan komponen-komponen PLTS dan pelatihan pemasangan PLTS

\subsection{Pemasangan Lampu Jalan Berbasis Solar Cell}

Setelah kegiatan pelatihan tentang pemasangan PLTS, kemudian dilakukan pemasangan lampu jalan berbasis solar cell di beberapa titik yang telah ditentukan sebelumnya. Pemasangan lampu jalan tersebut dapat membantu aktivitas civitas MA AlKhairiyah Rancaranji ketika berlangsung pada malam hari. Hal ini merupakan contoh penerapan langsung tentang pemanfaatan energi sinar matahari sebagai energi yang terbarukan. Sehingga dapat memotivasi civitas MA Al-Khairiyah Rancaranji untuk mempelajari lebih dalam tentang energi baru terbarukan.
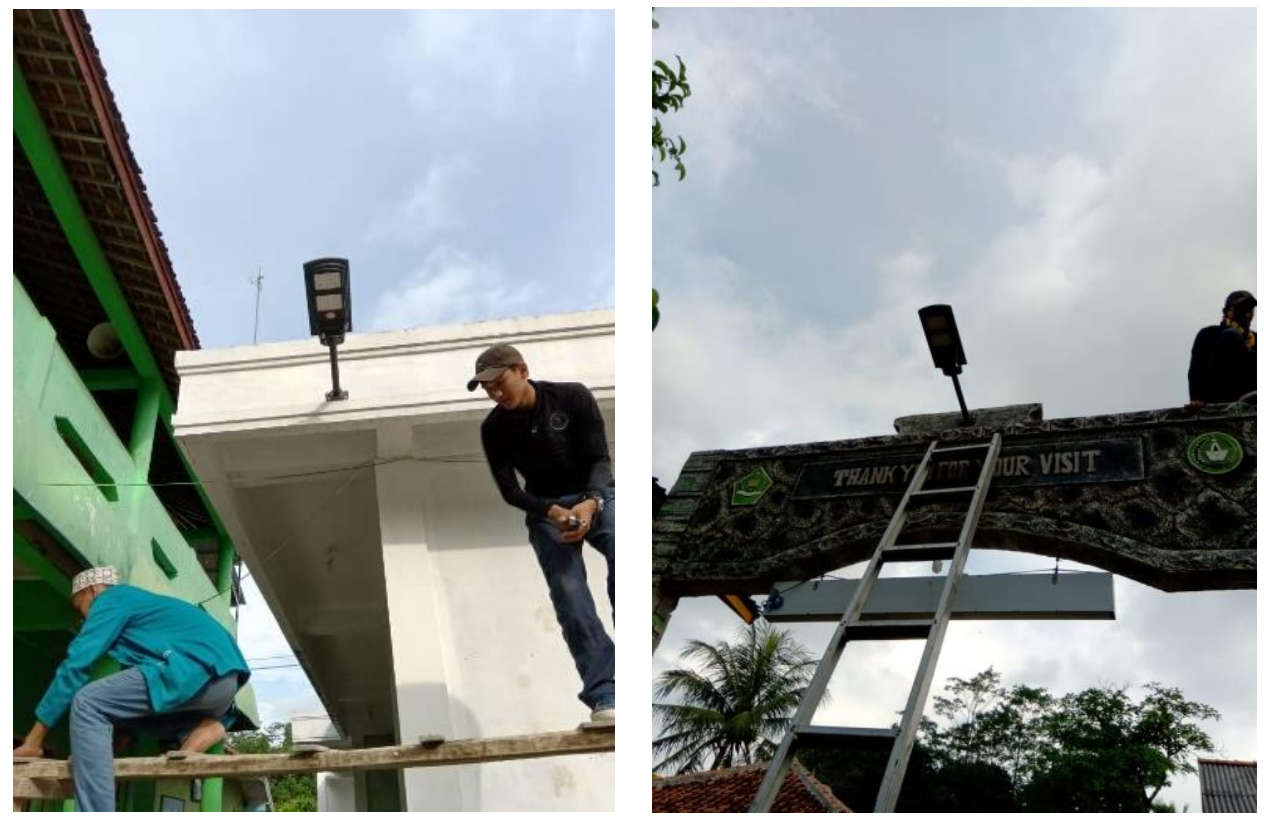

Gambar 6. Pemasangan Lampu Jalan Berbasis Solar Cell 


\section{KESIMPULAN DAN SARAN}

Berdasarkan kegiatan yang telah tim PKM IT-PLN lakukan di MA Al-Khairiyah Rancaranji dengan hasil pertemuan adalah kegiatan pengabdian kepada masyarakat khususnya civitas MA AlKhairiyah Rancaranji. Kegiatan tersebut berupa:

1. Pembelajaran tentang energi baru terbarukan untuk memperkenalkan potensi energi baru terbarukan yang ada di Indonesia

2. Pelatihan / Workshop pemasangan komponen-komponen pembangkit listrik tenaga surya.

3. Pemasangan lampu penerangan jalan berbasis solar cell penerapan langsung tentang pemanfaatan energi baru terbarukan yang berupa sinar matahari

Dari kegiatan tersebut dapat diketahui bahwa siswa-siswi MA Al-Khairiyah Rancaranji sangat antusias dalam mengenal tentang energi baru terbarukan dan dapat menerapkannya di lingkungan sekitar.

\section{UCAPAN TERIMA KASIH}

Dalam penyusunan dan pelaksanaan kegiatan Pengabdian Kepada Masyarakat ini kami ingin mengucapkan terima kasih kepada institusi dimana kami mengabdi yaitu Institut Teknologi PLN yang mendukung terlaksananya kegiatan PKM ini. Kami juga ingin menyampaikan terima kasih kepada Kepala sekolah MA Al-Khairiyah Rancaranji beserta guru-guru dan siswa/I yang telah memberikan sarana dan prasarana, serta antusias dan sambutan yang sangat baik sehingga kegiatan PKM ini dapat terlaksana. Tak lupa juga kami ucapkan terima kasih kepada mahasiswa-mahasiswa yang terlibat dalam membantu persiapan dan pelaksanaan kegiatan ini.

\section{DAFTAR PUSTAKA}

[1] APAMSI, Tim. 2013. "Pengembangan PLTS di Indonesia". Yogyakarta.

[2] Azzahra, Septianissa, dkk. 2019. "Pemasangan Lampu Jalan Berbasis Solar Cell untuk Penerangan Jalandi Desa Cilatak Ciomas. Vol 1 No 2 (2019): TERANG : Jurnal Pengabdian Pada Masyarakat Menerangi Negeri

[3] Duffie, A William, William A Beckman. 2008. "Solar Engineering of Thermal Process". John Wiley \& Sons. Newyork

[4] Hendra Riko, J. 2014. "Teknologi Energi dan Lingkungan Energi Terbarukan (PLTS)". Jurusan Teknik Mesin. Fakultas Teknik. Universitas Katolik Widya Karya.

[5] Kadir, Abdul. 2010. "Energi Sumber Daya, Inovasi, Tenaga Listrik dan Potensi Ekonomi”. UI Edisi Ke 3/ Revisi

[6] Timotius, Chris, dkk. 2009. "Perancangan dan Pembuatan Pembangkit Listrik Tenaga Surya”. Jurusan Pendidikan Teknik Elektro, Fakultas Pendidikan Teknologi dan Kejuruan, Universitas Pendidikan Indonesia.

[7] Christiono, C., Samsurizal, S., Pratama, R., Ratnasari, T., \& Fikri, M. (2019). Penyuluhan Pemanfaatan Energi Terbarukan (PLTS) di SMP IT Almaka Jakarta. TERANG, 2(1), 1015. 